\title{
Zdobycie Nowej Kartaginy przez Scypiona - problem interpretacji źródeł i ustaleń nowożytnej historiografii
}

\begin{abstract}
Abstrakt: Celem artykułu jest próba zweryfikowania najnowszych ustaleń dotyczących okoliczności zdobycia Nowej Kartaginy przez Publiusza Korneliusza Scypiona w 209 roku p.n.e. Zamiarem autora było ponowne przeanalizowanie relacji źródłowych i ich skonfrontowanie z treścią dyskursu w literaturze przedmiotu dotyczącego wskazanego tematu. Przebieg omawianej operacji, którą autor postanowił poddać krytycznej interpretacji, miał bowiem kolosalne znaczenie nie tylko dla dalszych walk Rzymian z Kartagińczykami na Półwyspie Iberyjskim, lecz także dla całego konfliktu potomków Romulusa z Hannibalem, w którym odnieśli oni ostateczne zwycięstwo.
\end{abstract}

Słowa kluczowe: Scypionowie, Korneliusze, Publiusz Korneliusz Scypion, Rzym, Kartagina, Hiszpania, druga wojna punicka, Nowa Kartagina

Spektakularne sukcesy Hannibala w Italii przesłaniają niekiedy wydarzenia, jakie miały miejsce na innych frontach drugiej wojny punickiej. Tymczasem punktem zwrotnym tego konfliktu było zdobycie Nowej Kartaginy wiosną 209 roku p.n.e. ${ }^{1}$ Mimo że od tego czasu upłynęło ponad 2200 lat, zdarzenie to nadal budzi w nauce dużo kontrowersji. Wielu autorów próbowało nadać mu własną interpretację, często sprzeczną z tą zawartą w źródłach antycznych. W niniejszym artykule podjęto

${ }^{1}$ R. GABRIEL: Scypion Afrykański Starszy, największy wódz starożytnego Rzymu. Tłum. J. JeDLiŃSki. Poznań 2010, s. 122; J. LAzenby: Wojna Hannibala. Historia militarna drugiej wojny punickiej. Tłum. T. Ładoń. Oświęcim 2015, s. 191; H. Scullard: Scipio Africanus in the Second Punic War. Cambridge 1929, s. 68; R. Chevallier: Voyages et déplacements dans l'Empire romain. Paris 1988, s. 114-120; F. Walbank: A Historical Commentary on Polybius. 2. Oxford 1967, s. 191-192; S. Ducin: Sztuka nawigacji w starożytnej Grecji i Rzymie. Lublin 1997, s. 62-63. 
próbę weryfikacji najnowszych ustaleń współczesnej nauki dotyczących zdobycia Nowej Kartaginy².

Wiosną 211 roku p.n.e. ojciec i stryj Publiusza Korneliusza Scypiona ${ }^{3}$ rozpoczęli tragiczną w skutkach kampanię przeciw Kartagińczykom. W jej wyniku obaj wodzowie zginęli na polu bitwy. Przed całkowitą klęską uchronił Rzymian trybun wojskowy Lucjusz Marcjusz ${ }^{4}$. Podjął on energiczne działania mające na celu zebranie resztek armii rzymskiej. Połączył siły z Tyberiuszem Fontejuszem ${ }^{5}$, a następnie w głosowaniu został obrany przez ocalałych z pogromu żołnierzy wodzem ${ }^{6}$. Udało mu się ufortyfikować obóz po północnej stronie rzeki Ebro i utrzymać rzymskie pozycje do nadejścia z Italii posiłków pod wodzą Gajusza Klaudiusza Nerona ${ }^{7}$. Według Liwiusza, Gajusz Klaudiusz Neron przeprowadził tylko jedną zaczepną operację militarną przeciwko Hazdrubalowi Barkasowi, w rejonie tzw. Czarnych Skał. Rzymianom udało się zamknąć Kartagińczyków w okrążeniu. Gajusz Klaudiusz Neron pozwolił jednak wymknąć się przeciwnikowi podczas prowadzonych pertraktacji .

W 210 roku p.n.e. po odwołaniu Gajusza Klaudiusza Nerona przez senat rzymski do Italii wodzem armii rzymskiej w Hiszpanii wybrano Publiusza Korneliusza Scypiona. Dowództwo sprawował jako privatus cum imperio9. Podjął on śmiałą kampanię przeciwko najważniejszemu miastu Hiszpanii kontrolowanemu przez Kartagińczyków. Nowa Kartagina miała fundamentalne znaczenie dla kartagińskiej

\footnotetext{
${ }^{2}$ M. Wolny: Hannibal w Italii (218-217 p.n.e.). Studia nad uwarunkowaniami początkowych sukcesów kartagińskich. Olsztyn 2007, s. 158-173.

${ }^{3}$ Chodzi o Publiusza Korneliusza Scypiona i Gajusza Korneliusza Scypiona.

4 T. Broughton: The Magistrates of the Roman Republic. I: 509 B.C.-100 B.C. New York 1951, s. 275. Lucjusz Marcjusz należał zapewne do warstwy ekwitów. Niewykluczone, że najpierw jako primipilus, a potem trybun wojskowy dał się poznać obu tragicznie zmarłym w Hiszpanii Scypionom jako odważny i godny zaufania oficer. Jego rodzina, prawdopodobnie o plebejskim rodowodzie, mogła być związana z rodem Korneliuszów na zasadach klienckich.

5 Tyberiusz Fontejusz był legatem Publiusza Korneliusza Scypiona. Po połączeniu się z wojskami Leliusza Marcjusza zgodził się na objęcie przez niego dowództwa.

6 Tytus Liwiusz: Dzieje Rzymu od założenia miasta. Tłum. M. Brożeк. Wrocław-WarszawaKraków 1974, XXV.37, XXVI.17, XXVI.19; R. Gabriel: Scypion Afrykański..., s. 83; J. LAZenby: Wojna Hannibala..., s. 190. Ich liczbę możemy szacować na ok. 6-8 tys. żołnierzy. Wiemy, że Publiusz Korneliusz Scypion po przybyciu na Półwysep Iberyjski dysponował armią 28 tys. pieszych i 3 tys. konnych. Biorąc pod uwagę, że Gajusz Klaudiusz Neron przywiódł do Hiszpanii 12 tys. pieszych i 1100 konnych. Z kolei Publiusz Korneliusz Scypion zabrał ze sobą z Italii ok. 10 tys. żołnierzy i 500 konnych. Na tej podstawie możemy szacować liczbę ocalałych żołnierzy.

7 Liwiusz XXV, 37; Frontyn: Podstępy wojenne. Tłum. B. Burliga. Wrocław 2016, VI, 2; S. DroźDzIEL: Przebieg i znaczenie kampanii Scypionów w Hiszpanii w latach 218-211 p.n.e. „Koło Historii" 2017, 20, s. 34.

${ }^{8}$ Liwiusz XXVI, 17.

${ }_{9}$ Sprawował imperium jako osoba prywatna, gdyż nie był pretorem ani konsulem. Por. J. LAzenby: Wojna Hannibala..., s. 191-192.
} 
obecności na Półwyspie Iberyjskim. Stanowiła bowiem główne zaplecze zbrojeniowe i logistyczne dla armii Kartaginy. Będąc najdogodniejszym portem na wybrzeżu Hiszpanii, dawała możliwość nieprzerwanej komunikacji z metropolią. Miasto to było także istotne ze względów strategicznych, gdyż znacząco utrudniało akcje ofensywne Rzymian w głębi Półwyspu Iberyjskiego, szachowało ono wrogie armie od południowego wschodu.

Przygotowany przez Publiusza Korneliusza Scypiona, w największej tajemnicy, plan kampanii miał pozbawić Kartagińczyków tego kluczowego miasta. Był on jednak bardzo ryzykowny, gdyż w wypadku niepowodzenia mógł zagrozić rzymskiej obecności w Hiszpanii ${ }^{10}$. Jeśli wierzyć Polibiuszowi, podstawą planu ofensywy Scypiona miały być obliczenia, których dokonał jeszcze przed przybyciem do Hiszpanii ${ }^{11}$. Nie wiadomo, skąd mógł czerpać wiedzę o sytuacji w Hiszpanii. Lecz o jego dobrym rozeznaniu w sprawach Półwyspu Iberyjskiego wiemy dzięki Polibiuszowi. Ten grecki historyk wspomina o liście, jaki rzymski wódz wysłał do Filipa Macedońskiego ${ }^{12}$. Publiusz Korneliusz Scypion deklarował w nim, że nie podjąłby żadnych działań, gdyby nie obliczenia, których dokonał. Chociaż źródło jego informacji pozostaje nieznane, to jednym z najbardziej możliwych wyjaśnień jego wiedzy o sytuacji strategicznej w Hiszpanii jest korespondencja prowadzona z zaufanymi oficerami jego ojca i stryja ${ }^{13}$. Według Polibiusza najważniejszą informacją było wskazanie, że żadna z wrogich armii ${ }^{14}$ nie znajduje się bliżej niż dziesięć dni drogi od Nowej Kartaginy ${ }^{15}$. Dzięki temu Scypion mógł być pewien, że wyruszając znad rzeki Ebro, dotrze do bram Nowej Kartaginy przed kartagińskimi armiami ${ }^{16}$.

${ }^{10}$ Liwiusz XXVIII, 17; J. PARKer: Comparing Strategies of the 2d Punic War: Rome's Strategic. Pennsylvania 2001, s. 19.

${ }_{11}$ Polibiusz: Dzieje. T. 1-2. Tłum. S. Hammer. Wrocław 1957, X, 7, 9.

12 Polibiusz X, 9; F. Walbank: A Historical Commentary..., s. 204.

13 Bardzo możliwe, że młody Scypion mógł od dłuższego czasu utrzymywać dobre kontakty z zaufanymi oficerami ojca i stryja. A uzyskaną od nich wiedzę wykorzystał do przygotowania swojego planu. Z drugiej strony pozostaje szczególny brak zaufania do Marka Sylanusa, którego przydzielił mu senat jako „wojskowego pomocnika”, a którego Scypion nie wtajemniczył w swoje plany. Por. LIwIUSz XXVI, 19.

${ }^{14}$ B. Lowe: Polybius 10.10.12 and the Existence of Salt-Flats at Carthago Nova. „Phoenix” 2000, 54, 1/2, s. 40; J. Lazenby: Wojna Hannibala..., s. 193. Armia Magona miała znajdować się w pobliżu słupów Heraklesa, armia Hazdrubala Giskona przebywała w Luzytanii, Hazdrubal Barkas zaś przebywał w okolicach dzisiejszego Toledo.

${ }^{15}$ Polibiusz X, 7; S. Lancel: Hannibal. Tłum. R. Wiśniewski. Warszawa 2001, s. 217; M. MACIEJOWsкi: Rzymski podbój Hiszpanii (218-178 przed Chr.), aspekty polityczne, militarne i społeczne. Oświęcim 2012, s. 99; K. Zimmermann: Roman Strategy and Aims in the Second Punic War. W: A companion to the Punic Wars. Red. D. Hoyos. [Wiley-Blackwell] 2015, s. 292. R. Gabriel (Scypion Afrykański..., s. 132-133) szacuje, że Kartagińczycy potrzebowaliby ok. miesiąca na zebranie rozproszonych oddziałów i zapewnienie im odpowiedniej logistyki oraz ok. 3 tygodni na dotarcie pod Nową Kartaginę.

${ }^{16}$ R. GabRIEL: Scypion Afrykański..., s. 132-133. 
Jak podkreślał Polibiusz, plany Scypiona były na tyle błyskotliwe, że nie przyszłyby do głowy ani Kartagińczykom, ani samym Rzymianom ${ }^{17}$. Richard Gabriel słusznie zaakcentował wagę, jaką miało rozmieszczenie armii kartagińskich dla całej planowanej kampanii przeciwko Nowej Kartaginie ${ }^{18}$. Szybkość działania oraz zaskoczenie przeciwnika były tu kluczowymi elementami.

Opis usytuowania Nowej Kartaginy zawdzięczamy Polibiuszowi. Znajdowała się ona na środku iberyjskiego wybrzeża, nad zatoką, która przybierała kształt naturalnego portu. Według Polibiusza miała długość dwustu stadiów, a szerokość u początku na 10 stadiów. Samo miasto leżało na górzystym półwyspie ciągnącym się od północnego wschodu. Był on otoczony wodami zatoki od wschodu i południa oraz płytką laguną od północy i zachodu. Od zachodu wybudowano most, który łączył miasto $\mathrm{z}$ lądem ${ }^{19}$.

Scypion przygotowując swój plan wyprawy na Nową Kartaginę, otrzymał od iberyjskich rybaków istotną informację. Dotyczyła ona warunków naturalnych panujących wokół Nowej Kartaginy. Niezwykle frapująca w ich relacji musiała być wzmianka o wspomnianej już płytkiej lagunie ulokowanej na północ od miasta. Przy silnym wietrze mogło w niej dojść do znacznego obniżenia poziomu wody, nawet o $1,5 \mathrm{~m}^{20}$. W konsekwencji umożliwiało to podejście pod mury miasta od strony laguny.

Po przybyciu na Półwysep Iberyjski (jesienią 210 roku p.n.e.) Scypion rozpoczął przygotowania do wiosennej kampanii. Nie mógł wszakże przewidzieć, jak długo Nowa Kartagina będzie w stanie się bronić. Hipotetycznie, gdyby kartagińskim armiom udało się przybyć szybkim marszem na odsiecz miastu, to położenie Rzymian mogło okazać się niezwykle groźne, gdyż znaleźliby się w okrążeniu. W takiej sytuacji jedyną możliwością wycofania się byłaby ewakuacja drogą morską ${ }^{21}$. Dlatego też w szczegóły operacji został wprowadzony (jako jedyny) Gajusz Leliusz ${ }^{22}$. Jako dowódca floty, musiał znać dokładne cele przygotowywanego planu, aby skutecznie koordynować działania sił morskich. W dniu wymarszu, wiosną 209 roku p.n.e.,

17 Polibiusz X, 6; H. Scullard: Scipio Africanus..., s. 65; F. Walbank: A Historical Commentary..., s. 201.

18 R. Gabriel: Scypion Afrykański..., s. 124-126.

19 Polibiusz X, 10; por. J. Lazenby: Wojna Hannibala..., s. 195. Polibiusz prawdopodobnie pomylił się w swoim opisie o co najmniej $45^{\circ}$ (północ u Polibiusza to północny wschód). Trzy opisywane przez niego wzgórza nie ciągnęły się w linii, a tworzyły wierzchołki trójkąta, zbyt duże są także podane wymiary Nowej Kartaginy.

20 J. Lazenby: Wojna Hannibala..., s. 196-197.

21 R. Gabriel: Scypion Afrykański.., s. 130; R. Laqueur: Scipio Africanus und die Eroberung von Neukarthago. „Hermes” 1921, 56, s. 158.

22 S. Lancel: Hannibal..., s. 217; P. Edwell: War Abroad: Spain, Sicily, Macedon, Africa. W: A companion to the Punic Wars. Red. D. Hoyos. [Wiley-Blackwell] 2011, s. 232; J. LAzEnBY: Wojna Hannibala..., s. 194; R. LAQueur: Scipio Africanus..., s. 153-154. 
Scypion zwrócił się do swoich żołnierzy, aby podnieść ich na duchu ${ }^{23}$. Nie zdradził im celu swojej operacji i dość enigmatycznie przedstawiał swoje plany, skupiając się na opisie bieżącej sytuacji militarnej ${ }^{24}$. Marek Sylanus ${ }^{25}$, którego Scypion nie wtajemniczył w swoje plany, otrzymał zadanie pozostania nad rzeką Ebro i ochraniania miejscowych rzymskich sojuszników. W tej misji miał go wspierać oddział żołnierzy liczący 3 tys. piechoty, ok. 500 jeźdźców oraz nieznaną liczbę sprzymierzeńców iberyjskich ${ }^{26}$.

Armia i flota wyruszająca razem ze Scypionem miała się poruszać od rzeki Ebro, wzdłuż wybrzeża, aż do Nowej Kartaginy ${ }^{27}$. Publiusz Korneliusz Scypion dysponował prawdopodobnie 25 tys. pieszych oraz 2,5 tys. konnych ${ }^{28}$. Równolegle do maszerujących wzdłuż wybrzeża żołnierzy płynęły okręty i statki z flotylli dowodzonej przez Gajusza Leliusza ${ }^{29}$. Zapewniało to mobilność całej armii.

Zarówno Polibiusz, jak i Liwiusz zgodnie podają, że Publiusz Korneliusz Scypion dotarł pod Nową Kartaginę w siódmym dniu marszu ${ }^{30}$ - Polibiusz czerpał swoją wiedzę na temat walk w Hiszpanii m.in. od Gajusza Leliusza, który jako dowódca floty musiał koordynować swoje poczynania $\mathrm{z}$ ruchem armii lądowej ${ }^{31}$. Z kolei u Appiana z Aleksandrii znajdujemy wzmiankę, że drogę tę armia rzymska pokonała w ciągu jednej nocy - co należy uznać za oczywistą pomyłkę autora lub błąd późniejszych kopistów ${ }^{32}$. Warto jednak pamiętać, że głównym założeniem

${ }^{23}$ H. Scullard: Scipio Africanus..., s. 61. W swojej przemowie Publiusz Korneliusz Scypion starał się wykazać, że stoi przed nimi niebywała okazja zmazania odium poprzedniej przegranej. Winą za wcześniejszą klęskę swego ojca i stryja obarczył sprzymierzone z Rzymianami ludy iberyjskie, które w decydującym momencie zdradziły swoich sojuszników.

${ }^{24}$ Polibiusz X, 6; por. R. Laqueur: Scipio Africanus..., s. 143. Rzymianie często podkreślali brak wspólnego działania Kartagińczyków i wzajemne waśnie ich wodzów. Jest to obraz zniekształcony. Podział kartagińskich sił był spowodowany w głównej mierze trudnościami aprowizacyjnymi. Suchy klimat oraz warunki terenowe nie sprzyjały dłuższej koncentracji wszystkich trzech kartagińskich armii.

${ }^{25}$ Liwiusz XXVI, 19; T. Broughton: The Magistrates..., s. 280; F. Walbank: A Historical Commentary..., s. 201. Marek Juniusz Sylanus był pretorem w 212 roku p.n.e., z woli senatu został wysłany do Hiszpanii w charakterze pomocnika Scypiona.

${ }^{26}$ Polibiusz X, 6. Por. Liwiusz XXVI, 42; B. Lowe: Polybius..., s. 40; R. Laqueur: Scipio Africanus..., s. 142; H. Scullard: Scipio Africanus..., s. 68. Liwiusz mówi o 3 tys. piechoty i tylko 300 konnych. Prawdopodobnie oprócz tych sił Marek Sylanus dowodził siłami złożonymi z miejscowych Iberów.

${ }^{27}$ Liwiusz XXVIII, 42; Polibiusz X, 6; R. Laqueur: Scipio Africanus..., s. 161.

${ }^{28}$ Polibiusz X, 9; M. Maciejowski: Rzymski podbój..., s. 101; F. Walbank: A Historical Commentary..., s. 204.

29 Polibiusz X, 9; J. Roth: The logistics of the Roman Army at war (264 B.C.-A.D. 235). Leiden-Boston-Köln 1999, s. 189-196; J. LAzenby: Wojna Hannibala..., s. 195.

${ }^{30}$ B. Lowe: Polybius..., s. 40.

${ }^{31}$ Polibiusz X, 3.

32 Polibiusz X, 9; Appian z Aleksandrii: Historia Rzymska. Tłum. L. Piotrowicz. Wrocław 1957, Wojny Hiszpańskie, 20; S. LANCEL: Hannibal..., s. 218. 
kampanii było zdobycie miasta przed upływem dziesięciu dni (z czego zapewne siedem dni Scypion przeznaczył na marsz, a trzy doby na szturm i opanowanie miasta), które to dawały mu poczucie bezpieczeństwa przed ewentualnym kontratakiem armii kartagińskich. Wiadomość o lokalizacji tych sił uzyskał najpewniej od oficerów służących w Hiszpanii ${ }^{33}$.

We współczesnej literaturze przytoczone informacje budzą najwięcej kontrowersji ${ }^{34}$. Oznaczają bowiem konieczność przebycia przez rzymską armię $450 \mathrm{~km}$ w zaledwie siedem dni ${ }^{35}$. W dyskursie naukowym powstało kilka hipotez, które starały się wyjaśnić to zagadnienie. Według jednej z nich Publiusz Korneliusz Scypion mógł wyruszyć z miejsca położonego znacznie bliżej Nowej Kartaginy, niż podano to w źródłach. W innych tekstach odnoszących się do tej kwestii odrzuca się tezę o siedmiodniowym marszu i wydłuża się znacząco czas potrzebny do pokonania tej trasy. Wreszcie pojawiają się sugestie, że Polibiusz mógł pomylić liczby lub też pomyłka wynikała $z$ uszkodzenia oryginalnego tekstu. Następnie błąd ten miał zostać powielony przez kolejnych antycznych autorów (m.in. Tytusa Liwiusza) ${ }^{36}$.

Richard Gabriel, właściwie jako jedyny, zaproponował interesującą hipotezę, według której pokonanie tej odległości przez oddziały Scypiona w ciągu siedmiu dni byłoby jednak możliwe. Według niego Rzymianie mogli pozostawić na tyłach większość wozów, a sprzęt oblężniczy i część zaopatrzenia załadowali na statki i przetransportowali je drogą morską. Ponadto zaopatrzyli się $\mathrm{w}$,żelazne racje” (suchary, suszone mięso), aby zmniejszyć niesiony ciężar. R. Gabriel domniemywał również, że Scypion mógł także zrezygnować $\mathrm{z}$ budowania obozów, w ten sposób zaoszczędzając wystarczająco dużo czasu i, o czym badacz nie wspomina, uwalniając legionistów od niesienia „palików wałowych”. Jednak jak sam zaznacza, nie ma na

${ }^{33}$ Oczywiście pokonanie $450 \mathrm{~km}$ w jedną noc należy wykluczyć, być może autorowi chodziło o ostatni etap marszu, który w celu zaskoczenia przeciwnika odbył się nocą.

${ }^{34}$ Literatura przedmiotu zasadniczo zgodnie odrzuciła tezę o siedmiodniowym marszu armii Scypiona znad rzeki Ebro do Nowej Kartaginy. Por. R. Gabriel: Scypion Afrykański..., s. 129; M. Maciejowski: Rzymski podbój..., s. 101; J. Lazenby: Wojna Hannibala..., s. 195; D. Lewis: Richard A. Gabriel, Scipio Africanus: Rome's Greatest General. Review. Duke University, s. 2; R. Laqueur: Scipio Africanus..., s. 157-158; F. Walbank: A Historical Commentary..., s. 204-205. Czy jednak możemy całkowicie odrzucić prawdziwość zgodnego przekazu źródłowego Polibiusza i Liwiusza? Należy podjąć także próbę rekonstrukcji tych wydarzeń, zgodnej z informacjami zawartymi w źródłach. Zasadniczo jedynie M. MACıEjowski (Rzymski podbój..., s. 101) traktuje rozważania R. Gabriela jako ciekawe tezy badawcze. Podkreśla jednak trudność ich zweryfikowania.

${ }_{35}$ M. Maciejowski: Rzymski podbój..., s. 101. Por. R. Gabriel: Scypion Afrykański..., s. 126, autor ten przyjmuje, że odległość między rzeką Ebro a Nową Kartaginą wynosi ok. 650 km. Z kolei M. Maciejowski wskazuje, że odległość ta wynosi jedynie $450 \mathrm{~km}$. Przy założeniu, że legioniści poruszali się możliwie najkrótszą trasą, odległość tę można zredukować do wspomnianych $450 \mathrm{~km}$ podanych przez M. Maciejowskiego.

${ }^{36}$ J. Lazenby: Wojna Hannibala..., s. 195. 
ten temat wzmianek w źródłach pisanych. Hipoteza R. Gabriela, choć niezwykle interesująca, nie została wystarczająco rozwinięta przez samego autora ${ }^{37}$.

Analizując treść wzmianek źródłowych i ustaleń literatury przedmiotu, należałoby przyjąć, że rzymski legionista, chcąc przemaszerować trasę ok. $450 \mathrm{~km}$ w ciągu siedmiu dni, musiałby pokonać dziennie odległość co najmniej $64 \mathrm{~km}$. Standardowo legioniści przemierzali drogę ok. 20-25 km (minimum $15 \mathrm{~km}$ ), a w przypadku pośpiesznego marszu nawet $30 \mathrm{~km}^{38}$. Zakładając, że przeciętny człowiek jest w stanie przejść ok. 5-6 km/h, to przy tej odległości musiałby maszerować co najmniej przez 11 godzin na dobę. Teoretycznie jest to możliwe. Znane są przykłady bardzo szybkiego przemarszu całych armii, które w ciągu doby pokonywały drogą lądową ok. $100 \mathrm{~km}^{39}$. Legioniści Scypiona zapewne podołaliby tak długotrwałemu wysiłkowi dzięki wyczerpującemu treningowi fizycznemu. Jak podaje Wegecjusz (który powołuje się m.in. na Katona Starszego), młody rzymski rekrut dla przygotowania swego organizmu do trudów dalekich przemarszów powinien przebywać dziennie ok. $30 \mathrm{~km}^{40}$. W przypadku żołnierzy Scypiona mamy do czynienia nie z rekrutami, ale w większości z weteranami długoletnich walk, w trakcie których byli oni zmuszeni do pokonywania bardzo dużych odległości. Możemy założyć, że Scypion zadbał o maksymalne odciążenie swoich legionistów tak, aby nie nieśli ze sobą zbędnego ekwipunku (ok. 20 kg uzbrojenia i 7 kg żywności). Rozpatrując to zagadnienie, należy wziąć pod uwagę możliwości, jakie dawało wykorzystanie okrętów i statków transportowych. Morze zapewniało Scypionowi najwydajniejszy sposób komunikacji i transportu ${ }^{41}$. Podróż morska była zdecydowanie szybsza i znacznie mniej męcząca od lądowej. Statek w ciągu dnia mógł standardowo pokonać trasę o długości ok. $100 \mathrm{~km}^{42}$. Flotylla, którą dysponował Gajusz Leliusz, mogła pokonać drogę do Nowej Kartaginy bez pośpiechu w ciągu 3-4 dni. R. Gabriel prawdopodobnie nie

37 R. GABRIEL: Scypion Afrykański..., s. 128-129.

38 Por. J. Wielowiejski: Na drogach i szlakach Rzymian. Warszawa 1984, s. 216.

39 Przeciętny człowiek porusza się z prędkością ok. $6 \mathrm{~km} / \mathrm{h}$, prędkość ta odpowiada dość szybkiemu marszowi. Przy założeniu, że legioniści maszerowali co najmniej 10-11 godzin dziennie, mogliby pokonać odległość ok. 60-66 km. Filip V w jedną dobę pokonał ponad $90 \mathrm{~km} \mathrm{-} \mathrm{zob.}$ LIwIUsz XXVIII, 7. Podobny dystans ok. 100 km w ciągu jednej doby przebył Serwiusz Galba wraz ze swym wojskiem w 151 roku p.n.e., zob. Appian: Wojny Hiszpańskie, 58.

40 Wegecjusz I, 19: „Tak więc w czasie miesięcy letnich należy przeprowadzić marsz na dystansie 20 mil rzymskich $(30 \mathrm{~km})$ i musi być on ukończony w ciągu pięciu godzin tempem wojskowym. Jeśli zastosujemy pełne tempo, które jest szybsze, w tym samym czasie należy przebyć dwadzieścia cztery mile rzymskie (ok. 35,5 km). Dalsze przyśpieszanie tempa obejmuje bieg, dla którego nie sposób określić dystansów” (tłum. A.M. KomornickA, s. 408-409). Por. H. PARker: Legiony rzymskie. Tłum. K. Narloch. Oświęcim 2013, s. 11-18.

${ }^{41}$ L. Casson: Podróże w starożytnym świecie. Tłum. A. Flasińska, M. Radlińska-Kardaś. Wrocław 1981, s. 105; R. Chevallier: Voyages..., s. 86; S. Ducin: Sztuka nawigacji..., s. 73-77; J. Roth: The logistics..., s. 189-196.

42 L. Casson: Podróże..., s. 107; S. Ducin: Sztuka nawigacji..., s. 74-75. 
doszacował możliwości transportowych floty Publiusza Korneliusza Scypiona. Przy swoich wyliczeniach wziął pod uwagę jedynie 30 kwinkwerem, o których wspomina Liwiusz $^{43}$. Tymczasem antyczni historycy często nie uwzględniali okrętów transportowych ${ }^{44}$. Potwierdzenie tego, że statki transportowe znajdowały się we flocie dowodzonej przez Gajusza Leliusza, znajdujemy we wzmiance Liwiusza. Rozróżnia on te dwie kategorie statków, gdy mówi o koncentracji rzymskich wojsk nad rzeką Ebro ${ }^{45}$. Dla ustalenia możliwości transportu armii drogą morską należy wziąć pod uwagę, że Publiusz Korneliusz Scypion przewiózł ze sobą z Italii ok. 10 tys. pieszych i 500 konnych $^{46}$. Nie mógłby pokonać takiej drogi jedynie na wspomnianych 30 kwinkweremach. Dysponował więc statkami, które mógł wykorzystać do transportu co najmniej $1 / 3$ swej armii lądowej (nie licząc zaopatrzenia, które ze sobą zabrał z Italii) ${ }^{47}$. Flota, która zapewne stanowi klucz do rozwiązania zagadki sukcesu Scypiona, mogła transportować znaczną część żołnierzy oraz ciężki sprzęt i zaopatrzenie, zwiększając tym samym mobilność armii lądowej. Zakładając, że standardowo jedna kwinkwerema mogła pomieścić 120 żołnierzy ${ }^{48}$, można przyjąć, że Scypion na samych okrętach wojennych jednorazowo był w stanie przewieźć co najmniej 3600 legionistów (dodatkowo wykorzystał zapewne statki transportowe). Być może część sił lądowych była transportowana drogą morską w sposób rotacyjny — tak, aby zapewnić żołnierzom konieczny wypoczynek i utrzymać szybkie tempo marszu. Powszechną praktyką w starożytności (ze względów bezpieczeństwa) było schodzenie na noc ze statków na brzeg. Rano legioniści, którzy wcześniej płynęli na okrętach, kontynuowaliby marsz trasą lądową, a ich miejsce na statkach zajmowaliby zmęczeni towarzysze broni, którzy dzień wcześniej przemieszczali się pieszo. Takie rozwiązanie pozwoliłoby na konieczny odpoczynek w trakcie marszu i redukowałoby znacznie dystans, jaki musiał pokonać pieszo żołnierz w drodze pod Nową Kartaginę. O współpracy i koordynacji działań armii i floty może świadczyć informacja, że dotarły pod Nową Kartaginę jednocześnie - siódmego dnia od wymarszu ${ }^{49}$.

${ }^{43}$ Liwiusz XXVI, 19; R. Gabriel: Scypion Afrykański..., s. 125, 127-130. R. Gabriel zauważa, że część armii lądowej faktycznie została załadowana na okręty, stwierdza jednak, że ze względu na niewielką ilość miejsca była to głównie obsługa artylerii.

${ }^{44}$ R. GABRIEL: Scypion Afrykański..., s. 119; S. Ducin: Typologia statków wykorzystanych do transportu morskiego wojsk w trakcie drugiej wojny domowej w Rzymie. „Annales” 1994, 49/11, s. 165.

${ }^{45}$ Liwiusz XXVI, 41: classem onerariasque - flocie i statkom transportowym.

${ }^{46}$ Appian: Wojny Hiszpańskie, 18; Liwiusz XXVI, 19. Publiusz Korneliusz Scypion wyruszył z Italii ze swoją flotą, z ujścia Tybru płynąc wzdłuż Morza Tyrreńskiego, Alp i Zatoki Gallickiej, następnie opłynął przylądek w pobliżu Pirenejów i wysadził wojska w Emporiach, aby ruszyć drogą lądową do Tarrakony. Według Liwiusza dysponował flotą 30 okrętów, z kolei Appian z Aleksandrii podał liczbę 28 okrętów wojennych.

${ }^{47}$ Liwiusz XXVI, 41.

48 S. Ducin: Typologia statków..., s. 166.

${ }^{49}$ Liwiusz XXVI, 41; N. Hooper, M. Bennett: Atlas sztuki wojennej w średniowieczu 7681487. Tłum. K. BAŻyŃsKa-СHојNACKA, P. СнојNACкI. Warszawa-Gdańsk 2004, s. 105. 
Rzymianie, już po przybyciu pod mury Nowej Kartaginy, przystąpili do budowy obozu. Umiejscowili go naprzeciw północnej części miasta. Scypion wykorzystał topografię terenu wokół Nowej Kartaginy, aby osłonić swój obóz przed ewentualnym atakiem. Miasto otaczało pięć pagórków, dwa z nich górzyste i strome, a kolejne trzy skaliste i trudno dostępne. Dla zabezpieczenia się przed ewentualną kartagińską odsieczą Publiusz Korneliusz Scypion nakazał wykopanie podwójnego rowu i wału. Jednak od strony miasta zaniechał wznoszenia jakichkolwiek umocnień. Prawdopodobnie zakładał, że załoga miasta będzie na tyle nieliczna, że nie odważy się zaatakować jego obozu. Korzyścią takiego rozwiązania była możliwość swobodnego wyboru miejsca do ataku oraz nieskrępowana możliwość manewrowania rzymskimi oddziałami ${ }^{50}$.

Publiusz Korneliusz Scypion chciał zająć miasto szturmem. W dniu ataku ogłosił, że plan zajęcia miasta objawił mu sam Neptun, który naocznie pokaże Rzymianom swoją przychylność w trakcie zbliżającej się bitwy ${ }^{51}$. Zapewne chodziło mu o wspomnianą już lagunę, która w wyniku działania wiatru i odpływu wody traciła swoją głębokość, dzięki czemu można było ją łatwo sforsowaćs2. Należy jednak zauważyć, że Publiusz Korneliusz Scypion przezornie nie skonkretyzował swoim żołnierzom, o jaką pomoc chodzi. W przypadku, gdyby odpływ nie nadszedł, nie zniechęciłoby to żołnierzy do kontynuowania szturmu na miasto ${ }^{53}$.

Obroną miasta dowodził Magon ${ }^{54}$. Dysponował ok. 1 tys. żołnierzy oraz 2 tys. uzbrojonych mieszkańców ${ }^{55}$. Podzielił on swoje siły, wysyłając pół tysiąca żołnierzy do obrony zamku, drugą połowę na wschodnie wzniesienie, aby stawili opór Rzymianom. Mieszkańców ustawił przy bramie wiodącej ku przesmykowi. Pozostali obywatele miasta mieli nieść pomoc w miarę możliwości tam, gdzie była ona potrzebna $^{56}$.

Scypion ustawił się na pagórku, aby móc obserwować przebieg bitwy oraz koordynować działania swoich wojsk, a jednocześnie być widocznym dla własnych

50 Polibiusz X, 11; J. Lazenby: Wojna Hannibala..., s. 196.

51 Polibiusz X, 11; R. Gabriel: Scypion Afrykański..., s. 136; F. Walbank: A Historical Commentary..., s. 192.

52 Polibiusz X, 7.

53 J. LAzenby: Wojna Hannibala..., s. 196-197.

${ }^{54}$ Niestety niewiele wiadomo na temat tego dowódcy; por. M. Wolny: Studia nad statusem i kompetencjami dowódców kartagińskich w okresie przewagi Barkidów (237-201 p.n.e.). Olsztyn 2013, s. 246.

55 Por. Appian: Wojny Hiszpańskie, 22. Appian podał, że obrońców było 10 tys. Trudno wierzyć w podaną liczbę, ponieważ miasto tak dobrze obwarowane z pewnością odparłoby rzymską armię. Co więcej, pomylił on Nową Kartaginę z Saguntem, co mocno podważa wiarygodność i szczegółowość jego przekazu; por. Appian: Wojny Hiszpańskie, 19. Znacznie bardziej szczegółową relację przekazuje nam Polibiusz. Por. też S. LAnCEL: Hannibal..., s. 217; M. Wolny: Studia nad statusem..., s. 246; K. Zimmermann: Roman Strategy..., s. 292.

56 Liwiusz XXVI, 44; M. Maciejowski: Rzymski podbój..., s. 102. 
ludzi ${ }^{57}$. Do ochrony dobrał sobie trzech ludzi, którzy trzymali przed nim tarcze i osłaniali go przed pociskami z miasta ${ }^{58}$. Plan ataku zakładał szturm na główną bramę miasta, aby odwrócić uwagę obrońców od przygotowywanej dywersji na niebroniony odcinek murów. Dzięki frontalnemu atakowi Rzymian, większość sił kartagińskich została całkowicie zaangażowana w obronę tego odcinka murów. Dodatkowo uwagę obrońców miała absorbować rzymska flota. Dzięki tej dywersji żołnierze, którzy w czasie szturmu zaatakowali od strony płytkiej laguny, mieli ułatwione zadanie ${ }^{59}$.

Szturm na miasto rozpoczęło 2 tys. legionistów z przygotowanymi drabinami. Zaatakowali główną bramę miasta. Jednocześnie, zgodnie z założeniami Scypiona, od strony morza do ataku przystąpiła flota pod wodzą Gajusza Leliusza, która ostrzeliwała miasto pociskami ${ }^{60}$.

Już na początku walk oddział kartagińskich żołnierzy zaatakował Rzymian przed samymi murami ${ }^{61}$. Scypion nakazał legionistom wycofywanie się $\mathrm{w}$ stronę obozu, dzięki czemu wywabił Kartagińczyków z dala od bramy ${ }^{62}$. Chociaż początkowo atak obrońców miasta był udany, Rzymianie szybko uporali się z przeciwnikiem ${ }^{63}$. Kartagińczycy wycofali się z trudem. Rzymianie, ścigając ich, niemal wdarli się do miasta. Mimo ogromnej przewagi atakujących pierwszy szturm został odparty. Wysokie mury okazały się bardzo trudne do sforsowania - Rzymianie mieli spadać $\mathrm{z}$ drabin lub też łamały się one pod ich ciężarem ${ }^{64}$. Po nieudanym ataku Scypion dał sygnał do odwrotu ${ }^{65}$. Następnie ustawił nowe wojska do kolejnego szturmu. Tym razem Rzymianie, wykorzystując większą liczbę drabin, postanowili zaatakować na całej długości murów. Na kolejny atak Kartagińczycy ponownie odpowiedzieli zaciętym oporem.

W trakcie tego szturmu rozpoczął się odpływ, dzięki czemu poziom wody w lagunie zaczął się obniżać. Widząc to, wydzielony oddział ok. 500 legionistów ruszył do ataku w okolicy miejsca dzisiaj zwanego Molino de Truchao ${ }^{66}$. Tego odcinka mu-

57 Por. Appian: Wojny Hiszpańskie, 21.

58 Liwiusz XXVI, 44.

59 P. Edwell: War Abroad: Spain..., s. 232.

${ }^{60}$ M. Maciejowski: Rzymski podbój..., s. 102-103; J. Lazenby: Wojna Hannibala..., s. 199. Polibiusz, co prawda, poinformował, że flota miała za zadanie przede wszystkim ostrzelanie miasta pociskami, jednakże Liwiusz (XXVI, 44) znacznie podniósł jej znaczenie, stwierdzając, że okręty przybijały do brzegu, a ich załogi atakowały mury $\mathrm{z}$ użyciem drabin.

61 Liwiusz XXVI, 44; J. LAzenby: Wojna Hannibala..., s. 198-199.

62 Polibiusz X, 14.

63 M. Wolny: Studia nad statusem..., s. 246; J. Lazenby: Wojna Hannibala..., s. 198-199.

${ }^{64}$ Liwiusz XXVI, 45; M. Maciejowski: Rzymski podbój..., s. 103; J. Lazenby: Wojna Hannibala..., s. 199.

65 Polibiusz X, 13; J. Lazenby: Wojna Hannibala..., s. 199.

${ }^{66}$ Liwiusz XXVI, 45. Por. Appian: Wojny Hiszpańskie, 21; J. Lazenby: Wojna Hannibala..., s. 199; S. LANCEL: Hannibal..., s. 220. 
rów (prawdopodobnie znajdującego się między Monte Molinete a Monte Sacro ${ }^{67}$ ) nie miał już kto bronić po stronie kartagińskiej. Rzymianie niepostrzeżenie dostali się pod mury, a po ich sforsowaniu, będąc już na terenie miasta, uderzyli od tyłu na obrońców. Zaskoczeni Kartagińczycy nie mogli powstrzymać tego nowego ataku ${ }^{68}$. Sytuacja obrońców stała się beznadziejna. Atak z zaskoczenia umożliwił Rzymianom sforsowanie głównej bramy i rozpoczęcie walk wewnątrz Nowej Kartaginy.

W tym miejscu mamy do czynienia z kolejną rozbieżnością między przekazem Polibiusza i Liwiusza. Według Polibiusza część rzymskich sił, które wdarły się przez bramę miejską, zajęła nadmorską część miasta Monte Concepcion, aby wspomóc oddziały atakujące od strony morza. Tymczasem według Liwiusza oddziały atakujące od strony morza wdarły się na mury miejskie w tej samej chwili co wojska lądowe ${ }^{69}$. Uwaga rzymskiego historyka jest chyba zasadna, biorąc pod uwage późniejszy spór, jaki wybuchł wśród żołnierzy Scypiona o tzw. wieniec murowy ${ }^{70}$.

Rzymianie, wpadając do miasta na rozkaz Scypiona, zaczęli mordować mieszkańców $^{71}$. Widząc, że miasto jest już stracone, Magon wysłał posłów z propozycją kapitulacji. Rzymski wódz zgodził się na nią i nakazał legionistom zaprzestania rzezi $^{72}$.

Przebieg tych wydarzeń nie jest jednak jednoznacznie oceniany. Szczególnie frapującą sugestię przedstawił wspominany R. Gabriel, który wysunął hipotezę, że celem kampanii Publiusza Korneliusza Scypiona nie było zdobycie Nowej Kartaginy, a jedynie sprowokowanie punickich dowódców do zorganizowania szybkiej odsieczy. Zajęcie Nowej Kartaginy badacz wytłumaczył tym, że dopiero na miejscu Scypion postanowił zaatakować miasto, w którym znajdował się zaskakująco słaby garnizon. Głównym założeniem planu rzymskiego wodza miałoby być rozbicie kolejno armii kartagińskich przybywających na odsiecz Nowej Kartaginie. Według drugiego scenariusza, tego samego autora, dzięki przewadze na morzu Publiusz Korneliusz Scypion próbowałby doprowadzić do wygranej bitwy z połączonymi siłami kartagińskimi. A taki plan mógł zrodzić się w głowie 25-latka ${ }^{73}$.

Sugestie te nijak się jednak mają do relacji Polibiusza ${ }^{74}$ i Liwiusza $^{75}$. Według nich Publiusz Korneliusz Scypion zdecydował się na próbę zajęcia Nowej Kartaginy głównie ze względów strategicznych. Nowa Kartagina była najważniejszym ośrodkiem władzy w Hiszpanii. Jako jedno z nielicznych miast posiadała port mogący

\footnotetext{
67 J. Lazenby: Wojna Hannibala..., s. 199.

68 Polibiusz X, 14.

69 J. Lazenby: Wojna Hannibala..., s. 199-200.

70 Por. Liwiusz XXVI, 48.

71 Liwiusz XXVI, 46; S. LAnCEL: Hannibal..., s. 220-221.

72 Polibiusz X, 15.

73 Por. R. Gabriel: Scypion Afrykański..., s. 130-133.

74 Polibiusz X, 9.

75 Liwiusz XXVI, 42.
} 
przyjmować flotę wojenną i dostarczającą zaopatrzenie. Tu też znajdował się skarbiec oraz zakładnicy gwarantujący lojalność miejscowych ludów. Dodatkowo zdobycie miasta oznaczałoby przejęcie kontroli nad warsztatami produkującymi broń i ekwipunek wojskowy oraz nad pobliskimi kopalniami srebra, które umożliwiały Kartaginie prowadzenie wojny $\mathrm{z}$ dotychczasowym rozmachem. Położenie miasta było także istotne ze względów strategicznych, gdyż szachowało ono Rzymian od południowego wschodu, znacząco utrudniając podjęcie akcji ofensywnych w tej części Półwyspu Iberyjskiego. Zdobycie Nowej Kartaginy, z rzymskiej perspektywy, miałoby również wielki wydźwięk propagandowy. Mogłoby wstrząsnąć fundamentami kartagińskiego panowania na całym terenie Hiszpanii. Jeśli wierzyć Appianowi z Aleksandrii, Publiusz Korneliusz Scypion zdawał sobie sprawę, że miasto było kartagińskim fundamentem panowania nad Hiszpanią ${ }^{76}$.

Nakreślona przez R. Gabriela perspektywa celów i zamierzeń strategicznych Publiusza Korneliusza Scypiona jest zatem błędna. Nie uwzględnia relacji Polibiusza, który pisał wprost, że Scypion obawiał się połączenia kartagińskich armii przed zajęciem Nowej Kartaginy. Rzymski wódz w takiej sytuacji rozważał ufortyfikowanie obozu, a następnie ewakuację drogą morską nad rzekę Ebro ${ }^{77}$. Priorytetem było zatem zdobycie Nowej Kartaginy, a konfrontacja z połączonymi siłami Kartagińczyków uniemożliwiłaby zajęcie miasta ${ }^{78}$. Wyciągając naukę z porażki swego ojca i stryja, starał się uniknąć walnej bitwy z Kartagińczykami ${ }^{79}$. Poza flotą Publiusz Korneliusz Scypion nie miał żadnej przewagi, która dawałaby mu nadzieję na pozytywny wynik starcia. Przy scenariuszu kreowanym przez R. Gabriela Rzymianie mieliby zagrożone linie zaopatrzenia. Do tego przewaga liczebna Kartagińczyków, gdyby zdołali połączyć swoje siły, byłaby przygniatająca ${ }^{80}$. Taki naiwny plan działania w bezpośredniej konfrontacji groził całkowitym unicestwieniem rzymskiej armii przez Kartagińczyków. Pojawia się także pytanie, dlaczego Publiusz Korneliusz Scypion nie zabrał ze sobą żadnych wojsk iberyjskich sprzymierzeńców (prawdopodobnie zostały pozostawione nad rzeką Ebro ${ }^{81}$. Gdyby faktycznie rozważał stoczenie decydującej bitwy z Kartagińczykami, powinien zmobilizować do tego celu wszystkie dostępne siły. Publiusz Korneliusz Scypion zdając sobie sprawę, że sukces jego kompanii będzie zależał od tego, jak szybko uda mu się podejść pod mury Nowej Kartaginy, wybrał żołnierzy zdyscyplinowanych, którzy nie będą opóźniać jego marszu.

${ }^{76}$ Appian: Wojny Hiszpańskie, 19; R. Laqueur: Scipio Africanus..., s. 158.

77 Polibiusz X, 8; R. Laqueur: Scipio Africanus..., s. 158-159.

78 Polibiusz X, 7; Liwiusz XXVI, 42.

79 R. Laqueur: Scipio Africanus..., s. 144.

${ }^{80}$ R. Laqueur: Scipio Africanus..., s. 157. Publiusz Korneliusz Scypion dysponował armią 25 tys. pieszych oraz 2,5 tys. konnych, przeciwko sobie miałby ok. 70-tysięczną armię kartagińską.

${ }^{81}$ F. Walbank: A Historical Commentary..., s. 204. 
Publiusz Korneliusz Scypion już po zajęciu miasta poświęcił wiele uwagi na przygotowanie swoich żołnierzy do walki. Nie tylko starał się wzmocnić ich wartość bojową, ale również zadbał o ich odpowiednie dozbrojenie. Aby wzmocnić siłę piechoty, polecił wcielić marynarzy z okrętów wojennych do oddziałów lądowych i szkolić na wzór legionistów. Dużo uwagi poświęcał również konnicy. Pieczę nad nią powierzył Leliuszowi. Trenował jeźdźców tak, aby byli w stanie dorównać przeciwnikom. Zdawał więc sobie sprawę ze słabości swojej armii i potrzeby jej wzmocnienia przed konfrontacją z Kartagińczykami ${ }^{82}$.

Warto zaznaczyć, że R. Gabriel swoją interpretację opisanych wydarzeń oparł w dużej mierze na przeświadczeniu, że Publiusz Korneliusz Scypion mógł nie uzyskać informacji dotyczących liczebności garnizonu znajdującego się w Nowej Kartaginie $^{83}$. I to podejście też jest błędne, gdyż w przekazie Polibiusza znajdujemy jasną informację o tym, że garnizon miasta liczył jedynie ok. tysiąca żołnierzy oraz że Publiusz Korneliusz Scypion dysponował tą wiedzą. Ta wiadomość zaważyła o podjęciu marszu na Nową Kartaginę ${ }^{84}$.

Opanowanie Nowej Kartaginy dało Publiuszowi Korneliuszowi Scypionowi wiele korzyści. Nie tylko pozbawił dzięki temu Kartagińczyków najdogodniejszego szlaku morskiego łączącego ziemie Kartagińczyków w Hiszpanii z ich metropolią w Afryce. Uwalniając przetrzymywanych w niewoli iberyjskich zakładników przebywających w mieście, zyskał ich sympatię i realnie zjednał sobie nowych miejscowych sojuszników. Z rąk kartagińskich Rzymianie przejęli kopalnie srebra położone nieopodal Nowej Kartaginy. A na bazie istniejących w mieście warsztatów i kuźni Scypion mógł rozpocząć wytwórstwo nowej broni i ekwipunku wojskowego dla swoich żołnierzy. Zdobycie Nowej Kartaginy stało się pierwszym etapem na drodze do budowy nowej rzymskiej armii w Hiszpanii i początkiem całkowitego wyparcia Kartagińczyków z Półwyspu Iberyjskiego.

82 Polibiusz X, 20.

83 R. Gabriel: Scypion Afrykański..., s. 129. Por. R. GABriel: Scypio Africanus: Rome’s Greatest General. Washington 2008, s. 91: „As far as we know, he had no knowledge of the Carthaginian garrison's size. It is puzzling how Scipio could have learned about the depth of the lagoon around the city, as Polybius claims, but not about the size of the city's garrison, which, in military terms, was far more important. It is possible, however, that Scipio knew the city was only lightly defended, and this information might have convinced him to strike quickly against it".

${ }^{84}$ Polibiusz X, 8; Appian: Wojny Hiszpańskie, 19. Appian podał informację jakoby w Nowej Kartaginie znajdował się garnizon liczący 10 tys. żołnierzy, to jednak wydaje się liczbą wielokrotnie zawyżoną. 
Artykuły

\section{Bibliografia}

Broughton T.: The Magistrates of the Roman Republic. I: 509 B.C.-100 B.C. New York 1951.

Casson L.: Podróże w starożytnym świecie. Tłum. A. FlasıńsKa, M. Radlińska-Kardaś. Wrocław 1981.

Chevallier R.: Voyages et déplacements dans l'Empire romain. Paris 1988.

DroźDziel S.: Przebieg i znaczenie kampanii Scypionów w Hiszpanii w latach 218-211 p.n.e. „Koło Historii" 2017, 20, s. 11-38.

DucıN S.: Sztuka nawigacji w starożytnej Grecji i Rzymie. Lublin 1997.

Ducin S.: Typologia statków wykorzystanych do transportu morskiego wojsk w trakcie drugiej wojny domowej w Rzymie. „Annales” 1994, 49/11, s. 165-178.

Edwell P.: War Abroad: Spain, Sicily, Macedon, Africa. W: A companion to the Punic Wars. Red. D. Hoyos. [Wiley-Blackwell] 2011, s. 320-328.

GABRIEL R.: Scypio Africanus: Rome's Greatest General. Washington 2008.

Gabriel R.: Scypion Afrykański Starszy, największy wódz starożytnego Rzymu. Tłum. J. JedLIŃsKi. Poznań 2010.

Hooper N., Bennett M.: Atlas sztuki wojennej w średniowieczu 768-1487. Tłum. K. BAżyńsKa-СHojnacka, P. Chojnacki. Warszawa-Gdańsk 2004.

LANCEL S.: Hannibal. Tłum. R. Wiśniewski. Warszawa 2001.

LAQUEUR R.: Scipio Africanus und die Eroberung von Neukarthago. „Hermes” 1921, 56, s. 131-225.

LAzEnBy J.: Wojna Hannibala. Historia militarna drugiej wojny punickiej. Tłum. T. ŁADoń. Oświęcim 2015.

Lewis D.: Richard A. Gabriel, Scipio Africanus: Rome’s Greatest General. Review, Duke University. Dostępne w Internecie: http://www.miwsr.com/2009/downloads/20090101.pdf (dostęp: 20.03.2019).

Lowe B.: Polybius 10.10.12 and the Existence of Salt-Flats at Carthago Nova. „Phoenix” 2000, 54, 1/2, s. $39-52$.

Maciejowski M.: Rzymski podbój Hiszpanii (218-178 przed Chr.), aspekty polityczne, militarne i społeczne. Oświęcim 2012.

Parker H.: Legiony rzymskie. Tłum. K. Narloch. Oświęcim 2013.

PARKer J.: Comparing Strategies of the 2d Punic War: Rome's Strategic. Pennsylvania 2001.

Rотн J.: The logistics of the Roman Army at war (264 B.C.-A.D. 235). Leiden-Boston-Köln 1999.

Scullard H.: Scipio Africanus in the Second Punic War. Cambridge 1929.

Walbank F.: A Historical Commentary on Polybius. 2. Oxford 1967.

WIELOWIEJSKI J.: Na drogach i szlakach Rzymian. Warszawa 1984.

Wolny M.: Hannibal w Italii (218-217 p.n.e.). Studia nad uwarunkowaniami początkowych sukcesów kartagińskich. Olsztyn 2007.

WolNy M.: Studia nad statusem i kompetencjami dowódców kartagińskich w okresie przewagi Barkidów (237-201 p.n.e.). Olsztyn 2013.

Zimmermann K.: Roman Strategy and Aims in the Second Punic War. W: A companion to the Punic Wars. Red. D. Hoyos. [Wiley-Blackwell] 2015, s. 280-298. 


\section{Capturing New Carthage (Cartagena) by Scipio - the problems related to sources interpretation and to findings of modern historiography}

In the year $211 \mathrm{BCE}$, Romans suffered one of the most devastating defeats during the Second Punic War. Their unsuccessful offensive undertaken by Publius Cornelius Scipio and Gnaeus Cornelius Scipio resulted in loss of the territories previously conquered in Hispania and deaths of the two Scipiones.

Gaius Claudius Nero was then appointed to Hispania, having been chosen the new commander by the Centuriate Assembly. He was affiliated with the Fabii faction that by his nomination seized the control over that theatre of war. However, a decisive action by the Cornelii, aimed at regaining the lost influence, prompted his recall.

Publius Cornelius Scipio the Elder applied for the vacancy and became the army commander in Hispania. Having reached the Iberian Peninsula, Scipio undertook vigorous actions in order to capture New Carthage. He utilised his fleet to increase the mobility of his troops, to subsequently set about marching towards to Carthaginians' city. Seizure of the city proved to be the turning point, after which the Carthaginian rule in Iberia waned. It also brought about the eventual Roman victory. Key word s: Scipiones, Publius Cornelius Scipio, Roma, Hispania, New Carthage, Second Punic War 